\title{
Benthic microbial metabolism in seagrass meadows along a carbonate gradient in Sulawesi, Indonesia
}

\author{
D. M. Alongi ${ }^{1, *}$, L. A. Trott $^{1}$, M. C. Undu ${ }^{2}$, F. Tirendi ${ }^{1}$ \\ ${ }^{1}$ Australian Institute of Marine Science, PMB 3, Townsville MC, Queensland 4810, Australia \\ ${ }^{2}$ Research Institute for Coastal Aquaculture, Jl. Makmur Dg. Sittaka, Maros, Sulawesi 90511, Indonesia
}

\begin{abstract}
Sediment carbon and nitrogen cycling were examined in tropical seagrass meadows across a gradient of increasing carbonate content during wet and dry seasons in Awerange Bay, Sulawesi, Indonesia. Coincident with an increase in seagrass and microalgal productivity, increases in rates of sulfate reduction, ammonification, $\mathrm{O}_{2}$ consumption, nitrogen fixation, $\mathrm{CH}_{4}$ release, carbonate dissolution, and pore water concentrations and fluxes of $\mathrm{H}_{2} \mathrm{~S}$ were observed across the gradient. These increases occurred despite a decline in particulate nutrient and dissolved iron concentrations in the sediment. Sulfate reduction appeared to be the dominant decomposition pathway, with rates ranging from 27-68 $\mathrm{mmol} \mathrm{S} \mathrm{m}^{-2} \mathrm{~d}^{-1}$ inshore to $53-98 \mathrm{mmol} \mathrm{S} \mathrm{m}^{-2} \mathrm{~d}^{-1}$ in the outer bay. Rapid rates of carbon oxidation were matched by rapid rates of $\mathrm{N}$ transformation, with ratios of $\mathrm{C}$ and $\mathrm{N}$ mineralization rates close to the sediment $\mathrm{C}: \mathrm{N}$ ratio. Denitrification (range: 1022 to $1897 \mu \mathrm{mol} \mathrm{N} \mathrm{m}{ }^{-2} \mathrm{~d}^{-1}$ ) equated to $\sim 25 \%$ of ammonification, with the proportion decreasing from $19-53 \%$ inshore to $0.5-17 \%$ offshore. The patterns of increase in $\mathrm{C}$ and $\mathrm{N}$ cycling were attributed to greater water clarity along the gradient, allowing greater light levels to foster higher rates of seagrass productivity and, in turn, increased rates of mineralization and carbonate dissolution.
\end{abstract}

KEY WORDS: Bacteria $\cdot$ Carbon $\cdot$ Carbonate dissolution $\cdot$ Nitrogen $\cdot$ Seagrass $\cdot$ Sediment $\cdot$ Indonesia

\section{INTRODUCTION}

Seagrass meadows are important coastal habitats, supplying a number of crucial ecosystem services along many temperate and tropical shoal coasts. Seagrasses are usually highly productive, supplying fixed carbon as food for numerous commercially important species. They also supply habitat for organisms, which live on and within sediments, in the overlying water column, and as epiphytes on grass blades (Hemminga \& Duarte 2000). Both resident and transitory organisms form rich and complex food webs that define seagrass ecosystems as ecologically and energetically diverse.

Seagrass meadows are important ecosystems from a biogeochemical perspective, as high rates of primary production, a rich fauna and flora, and the curtailment of water flow leading to enhanced settlement of fine particles suggest that organic matter deposits within the understory and onto sediments, sustaining high rates of energy and nutrient flow (Marbà et al. 2006). Coupled with their metabolic activities from blade tip to roots, the net import of organic matter enhances microbial decomposition and subsequent regeneration of dissolved nutrients back to the plants and/or into the overlying water column (Mateo et al. 2006). Seagrass and microbial metabolic activities also modify the physical and chemical conditions of the overlying water and sediments. For instance, many seagrasses pump oxygen to their roots and rhizomes, which provides an oxic zone around the roots that greatly affects plant-microbe-nutrient relationships (Duarte et al. 2005).

Seagrass-microbial relationships, especially rates and pathways of nutrient transformation, are also greatly affected by sediment type and texture (Gacia et al. 2003). For example, seagrasses enhance dissolution of carbonate sediments (Burdige \& Zimmerman 2002, Holmer et al. 2003, Barrón et al. 2006, Hebert et 
al. 2007, Hu \& Burdige 2007). This process comes about by the exudation of dissolved organic carbon (DOC) and $\mathrm{O}_{2}$ via seagrass roots, stimulating microbial respiration, which generates carbonic acid to dissolve calcium carbonate. High concentrations of dissolved inorganic carbon (DIC) in pore water cannot be explained solely by DIC generated by microbial oxidation of organic matter. In the Bahamas, Burdige \& Zimmerman (2002) estimated that carbonate dissolution in sediments colonized by seagrasses occurs at rates of 4 to $11 \mathrm{mmol} \mathrm{CaCO}_{3} \mathrm{~m}^{-2} \mathrm{~d}^{-1}$, tending to increase with shoot density.

Seagrasses also enhance nitrogen cycling in sediments, especially the production of ammonium, by releasing dissolved organic nitrogen (DON) via the roots, stimulating bacterial decomposition (Romero et al. 2006). In tropical seagrass beds, nitrogen fixation may provide $>50 \%$ of plant $\mathrm{N}$ demand, and high sulfate-reducing activity suggests that sulfate-reducing bacteria may be partly responsible for the fixation of nitrogen (Welsh 2000). How rates of sulfate reduction relate to the overall cycling of nitrogen in tropical seagrass sediments is not understood; also not understood is how rates and pathways of microbial oxidation of sediment organic matter vary in relation to changes in $\mathrm{CaCO}_{3}$ content.

In this paper, we describe how simultaneous measurements of benthic carbon and nitrogen cycling, and estimated rates of carbonate dissolution from rates of Ca efflux, change along a sediment gradient of increasing carbonate content, and how these processes relate to leaf productivity of one of the dominant seagrasses, Enhalus acoroides, in a small bay in Indonesia.

\section{MATERIALS AND METHODS}

Study sites. The study was conducted in Awerange Bay, located on the southwest coast of the island of Sulawesi, Indonesia, in Barru Regency (Fig. 1). The bay is crescent-shaped, $5.4 \mathrm{~km}^{2}$ in area with a $1.2 \mathrm{~m}$ tidal range and mean depth of $14 \mathrm{~m}$, with fringing coral reefs occupying most of the bay entrance and mangroves and seagrass beds inhabiting most of the southern end of the bay. The climate in this area is seasonal; the wettest months are from December to May, with annual rainfall ranging from 2000 to $3000 \mathrm{~mm}$ (Whitten et al. 1987, Chuan 2005).

Three seagrass beds along the southern bay (Fig. 1) were sampled in the dry season (September 2006) and the wet season (March 2007). Stn SG1 was located a

few metres from the mouth of a small mangrove-lined creek located in the southeast section of the bay. Stn SG2 was adjacent to a small village located further seawards, and Stn SG3 was located near the mouth of the bay at the southwest corner, between a fringing coral reef and a small mangrove forest. About 15 to $20 \mathrm{~cm}$ beneath the seagrass beds lie dead coral reef, interspersed with unconsolidated carbonate sediments ranging in size from small particles to large $(5$ to $30 \mathrm{~cm}$ wide) dead coral heads.

Total seagrass densities at these 3 sites range from 659 to 2062 shoots $\mathrm{m}^{-2}$ (Fig. 2a), with greater densities at Stn SG3 than at Stn SG2 in the wet season; dry season differences among sites were not significant but densities were greater at Stn SG3 in the wet than in the dry season (Sarinita \& Priosambodo 2006). Halodule uninervis is the numerically dominant species followed by either Cymodocea rotundata or C. serrulata and lower densities of Thalassia hemprichii and Enhalus acoroides (Sarinita \& Priosambodo 2006). As E. acoroides was the dominant biomass, only the production of this species was measured by Priosambodo (2006). Production rates of E. acoroides (Fig. 2b) increased from Stns SG1 (range: 0.4 to $1.4 \mathrm{~g}$ dry weight [DW] $\mathrm{m}^{-2}$ $\mathrm{d}^{-1}$ ) to SG2 (range: 0.9 to $3.5 \mathrm{~g} \mathrm{DW} \mathrm{m}^{-2} \mathrm{~d}^{-1}$ ) to SG3 (range: 9.7 to $11.7 \mathrm{~g} \mathrm{DW} \mathrm{m}^{-2} \mathrm{~d}^{-1}$ ). Production is greater in the dry season than in the wet season (Fig. 2b) only at Stn SG2 (Priosambodo 2006).

Sediment sampling and elemental analysis. Triplicate sediment samples were taken at each site at low tide using a handheld stainless steel corer $(7 \mathrm{~cm}$ inner diameter [i.d.]) containing an inner plastic core of $2 \mathrm{~cm}$ rings with punch holes to allow insertion of $\mathrm{pH}$ and redox electrodes. At each site, 3 additional sediment cores $(n=3)$ were taken to a depth of maximum penetration $(\sim 18$ to $20 \mathrm{~cm})$ for measurement of particulate 

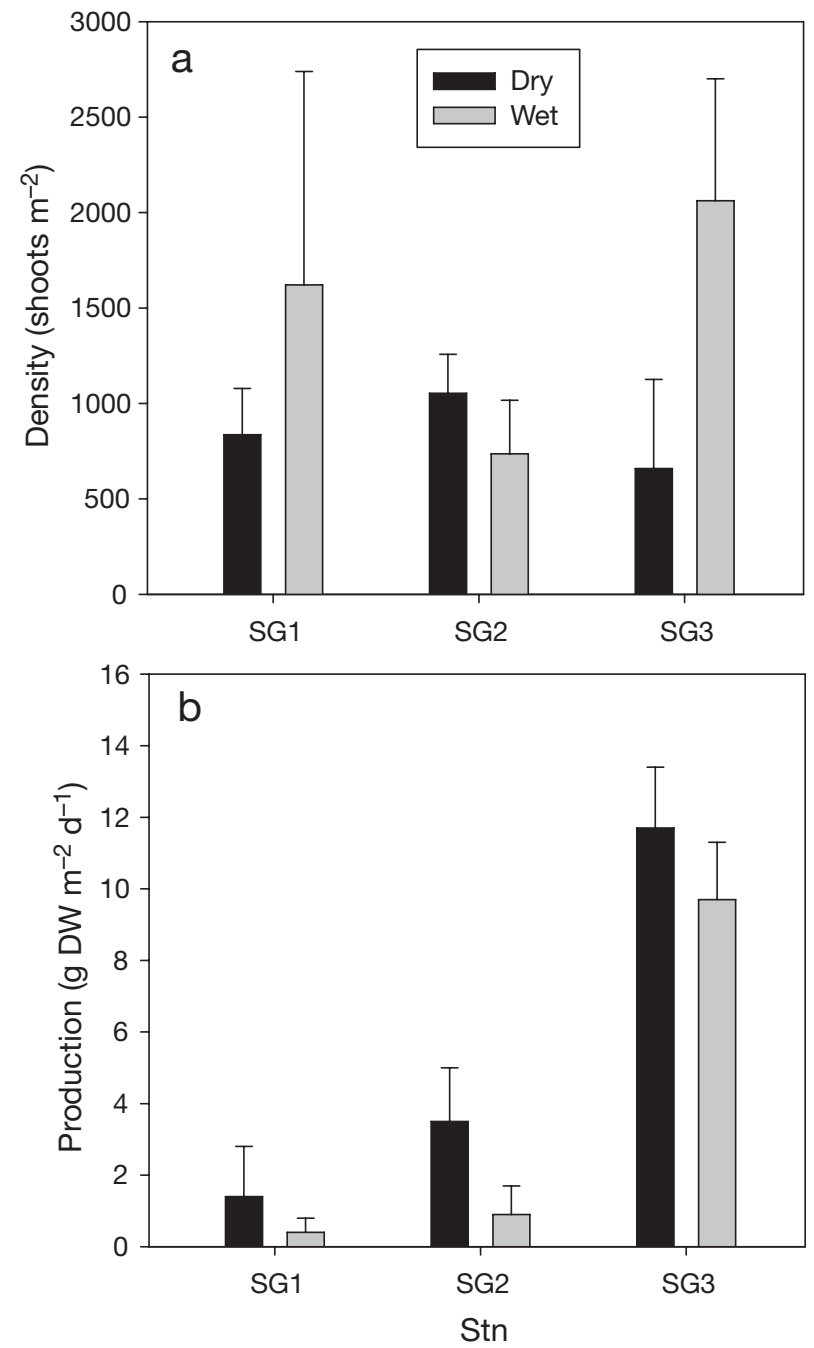

Fig. 2. (a) Mean ( $\pm 1 \mathrm{SE})$ total densities of live seagrass shoots and (b) daily net production of Enhalus acoroides in the dry and wet seasons at the 3 seagrass sites. Density data are from Sarinita \& Priosambodo (2006) and production data from Priosambodo (2006)

nutrients and other elements and for net ammonium production; triplicate $2.7 \mathrm{~cm}$ diameter plastic cores were taken separately to measure sulfate reduction, and shallower cores were taken (see 'Solute fluxes') for measurement of solute transport across the sediment-water interface. All cores excluded seagrass.

$\mathrm{pH}$ and redox potential (Eh) were measured sequentially using calibrated Model PBFC pH and calomel Eh electrodes connected to a TPS LC 80 meter. Analysis of sediment grain size and sorting were performed on a Malvern Mastersizer 2000. Sediments were classified based on the definitions in Folk (1974). Subsamples were taken at $2 \mathrm{~cm}$ intervals and frozen at $-20^{\circ} \mathrm{C}$. On return to the laboratory, they were wet- and dryweighted to determine water content, and ground to a fine powder for determination of total $\mathrm{C}$ and total $\mathrm{N}$ on a Perkin-Elmer 2400 CHNS/O Series II Analyzer and for total organic carbon (TOC) on a Shimadzu TOC Analyzer with solid sampler. For TOC, a small volume (usually $100 \mu \mathrm{l}$ ) of $2 \mathrm{M} \mathrm{HCl}$ was added to the sediment, and the sample was then evaporated to dryness and combusted at $950^{\circ} \mathrm{C}$. Total $\mathrm{P}$ was determined after strong acid digestion on a Varian Liberty inductively coupled atomic emission spectrometer following the procedure of Loring \& Rantala (1992). Total inorganic carbon was assumed to be incorporated into $\mathrm{CaCO}_{3}$, as determined by the difference between the total $\mathrm{C}$ and TOC concentrations. Samples (5 to 10 live shoots) of the seagrasses Enhalus acoroides, Cymodocea rotundata and Halodule univervis were taken from each site and processed identically for total C, TOC, total $\mathrm{N}$ and $\mathrm{P}$.

Sulfate reduction. Rates of sulfate reduction were measured from triplicate $2.7 \mathrm{~cm}$ diameter plastic cores taken to the depth of maximum penetration. In the field, the cores were capped at both ends and injected at $1 \mathrm{~cm}$ intervals with carrier-free ${ }^{35} \mathrm{SO}_{4}$. The samples were then incubated for 9 to $18 \mathrm{~h}$, and then terminated by fixing sediments in $20 \%$ zinc acetate. Samples were then frozen at $-20^{\circ} \mathrm{C}$ until a 2-step distillation procedure (Fossing \& Jorgensen 1989) was used to determine the fraction of reduced radiolabel shunted into the acid-volatile sulfide (AVS) and chromiumreducible sulfur (CRS) pools.

Solute fluxes. Solute fluxes across the sedimentwater interface were measured from 3 opaque and 3 clear chambers (volume: $1 \mathrm{l}$; area: $82 \mathrm{~cm}^{2}$ ) from which DIC, $\mathrm{O}_{2}$, and dissolved inorganic nutrient $\left(\mathrm{NH}_{4}{ }^{+}, \mathrm{NO}_{2}{ }^{-}\right.$ $\left.+\mathrm{NO}_{3}{ }^{-}, \mathrm{PO}_{4}{ }^{3-}\right)$ and other solute $\left(\mathrm{Ca}, \mathrm{Fe}, \mathrm{Mn}, \mathrm{H}_{2} \mathrm{~S}\right)$ samples were taken at $1 \mathrm{~h}$ intervals for 4 to $6 \mathrm{~h}$. The samples were taken by divers by gently inserting the open bottom of the chambers into the sediment between seagrass shoots to a sediment volume of 300 to $400 \mathrm{~cm}^{3}$. An inert rubber plate was slipped under the chamber and sealed into a PVC cap before withdrawing the chamber from the seabed. The chambers were then returned to the laboratory and were incubated under shade cloth (to mimic in situ light as much as possible) in a running seawater bath to maintain ambient seawater temperature. Each chamber had a propeller-electric motor unit and 2 sampling ports on opposite sides of the chamber (Alongi et al. 2006). Dissolved oxygen was measured in dark and light chambers using an $\mathrm{O}_{2}$ probe (TPS Model WP-82 DO meters) placed into 1 sampling port; the other port was fitted with plastic tubing to draw off $10 \mathrm{ml}$ samples for solutes. The oxygen data from the light and dark bottles were used to estimate benthic microalgal production; data were logged from 10:00 to 14:00 h, and it was assumed that this period incorporated one-half of average daylight. 
The samples for DIC and dissolved inorganic nutrients were filtered (0.45 $\mu \mathrm{m}$ Minisart filters) and either kept cool and dark (DIC) or frozen at $-20^{\circ} \mathrm{C}$ until analysis. Concentrations of $\mathrm{NH}_{4}{ }^{+}, \mathrm{NO}_{2}{ }^{-}+\mathrm{NO}_{3}{ }^{-}$and $\mathrm{PO}_{4}{ }^{3-}$ were determined using automated techniques (Ryle et al. 1981, Ryle \& Wellington 1982). Concentrations of DIC and $\mathrm{H}_{2} \mathrm{~S}$ were determined using the procedure of Hall \& Aller (1992) to measure DIC and that of Lustwerk \& Burdige (1995) to measure DIC in the presence of $\mathrm{H}_{2} \mathrm{~S}$. The concentration of $\mathrm{H}_{2} \mathrm{~S}$ was estimated by the difference between these 2 values. Accuracy was within $7 \%$, as determined by using a set of $\mathrm{H}_{2} \mathrm{~S}$ standards. Dissolved Fe, Mn, Ca and S concentrations were determined from filtered (0.45 $\mu \mathrm{m}$ Minisart filters) samples on the Varian ICP-MS.

Net $\mathrm{NH}_{4}{ }^{+}$production. Rates of net $\mathrm{NH}_{4}{ }^{+}$production from sediments were measured by incubating 2 sets of triplicate sediment cores taken at low tide from each site (Alongi et al. 2006). One set of cores was sliced immediately at $2 \mathrm{~cm}$ intervals and then 1 to $5 \mathrm{ml}$ (depending on pore water volume) of $1 \mathrm{M} \mathrm{KCl}$ solution was added and mixed into each sample to release fixed $\mathrm{NH}_{4}{ }^{+}$. After $2 \mathrm{~h}$, the samples were centrifuged to obtain pore water that was filtered $(0.45 \mu \mathrm{m})$ and placed into sterile plastic test tubes and frozen at $-20^{\circ} \mathrm{C}$ until the measurement of total extractable $\mathrm{NH}_{4}{ }^{+}$. The other set of cores was mixed, with subsamples placed in large opaque glass bottles that were hermetically sealed and then incubated at in situ temperature for $6 \mathrm{~d}$. After incubation, the samples were processed in the same way as the other set of cores. From the first set of cores, small (1 to $2 \mathrm{ml}$ ) subsamples of pore water were taken prior to $\mathrm{KCl}$ addition, filtered, and analyzed for $\mathrm{Cl}_{1} \mathrm{H}_{2} \mathrm{~S}$, $\mathrm{Fe}$ and $\mathrm{Mn}$ as described in the section 'Solute fluxes'.

Denitrification and nitrogen fixation. Denitrification was measured from replicate sediment samples using the $\mathrm{N}_{2}$-gas flux technique (Nowicki 1994). Fluxes of $\mathrm{CH}_{4}$ and $\mathrm{N}_{2} \mathrm{O}$ were measured in the same chambers (oxic chambers only). $\mathrm{CH}_{4}$ and $\mathrm{N}_{2} \mathrm{O}$ accumulation rates in the gas headspaces were considered de novo synthesis and were calculated as the average rate of triplicate cores from each station. Open-ended bottles were carefully pushed 8 to $10 \mathrm{~cm}$ into the sediment (volume: $385 \mathrm{~cm}^{3}$ ) and samples were kept at ambient temperature in an aerated running seawater bath after return to the laboratory. Any obvious surface fauna was removed with tweezers before each sample was extruded into a gas-tight glass chamber (height = $23.5 \mathrm{~cm}$; i.d. $=7.6 \mathrm{~cm}$ ). Sediments in each chamber were covered with seawater sparged with either $80 \%$ $\mathrm{He}: 20 \% \mathrm{O}_{2}$ mixture (4 experimental chambers per site) or $100 \% \mathrm{He}$ ( 2 to 3 control chambers per site) to remove $\mathrm{N}_{2}$ and, in the case of the experimental cores, to maintain dissolved $\mathrm{O}_{2}$ concentrations. The overlying water in each sealed chamber was stirred continu- ously. All chambers were incubated for $7 \mathrm{~d}$ in the dark at ambient temperature.

In the experimental chambers, the gas phase was flushed every $8 \mathrm{~h}$ for the first $2 \mathrm{~d}$ with an $80 \% \mathrm{He}: 20 \%$ $\mathrm{O}_{2}$ mixture, and again (after the water overlying the sediment was periodically replaced with low $-\mathrm{N}_{2}$ seawater) after $3 \mathrm{~d}$. The control chambers were treated similarly but incubated under anoxic conditions to block nitrification and denitrification (Alongi et al. 2006). Background de-gassing of $\mathrm{N}_{2}$ in the control chambers was subtracted from the total $\mathrm{N}_{2}$ flux measured in the experimental chambers to derive the rate of $\mathrm{N}_{2}$ flux caused by denitrification (Nowicki 1994). Denitrification rates were calculated as the average rate of triplicate cores from each site, from 3 to 4 individual incubation periods.

Nitrogen fixation in sediments at each site was measured in 3 to 4 dark and clear chambers using the acetylene reduction technique (Capone 1993). Samples were taken by inserting open-ended chambers (surface area: $64 \mathrm{~cm}^{2}$ ) into the sediment to a depth of $5 \mathrm{~cm}$. The chambers and soil plugs were then gently withdrawn with minimal disturbance. The bases of the chambers were sealed with PVC caps containing an inert rubber plate. A $10 \%$ acetylene:air mixture was created (sediment volume: $320 \mathrm{~cm}^{3}$ ), added to the water phase, and the headspace was sampled immediately and at $3 \mathrm{~h}$ intervals, with a final sampling at $20 \mathrm{~h}$. Acetylene and ethylene were analyzed simultaneously by gas chromatography. The ethylene rates were converted to rates of $\mathrm{N}_{2}$ fixation using the theoretical factor of $3 \mathrm{C}_{2} \mathrm{H}_{2}$ molecules equalling $1 \mathrm{~N}$ molecule (Capone 1993).

Statistics. Differences in parameters were tested using either 1-way (site), 2-way (site $\times$ depth) or 3-way (site $\times$ depth $\times$ season) ANOVA (Sokal \& Rohlf 1995) followed by Ryan's Q-test (Day \& Quinn 1989) for multiple comparisons when significant main effects were found. If necessary, data were square root-transformed. Flux rates were determined by least-squares regression, and relationships among variables were explored using Pearson's correlation analysis. Results were compared at the $5 \%$ level of significance.

\section{RESULTS}

\section{Benthic microalgal production}

Rates of benthic microalgal production (Fig. 3) mirrored the production pattern of Enhalus acoroides among sites, with rates of leaf production in the following order by station: SG3 > SG2 > SG1. Seasonal differences were significant at Stn SG1, where production was higher in the dry season, and at Stn SG3, where rates were higher in the wet season (Fig. 3). 


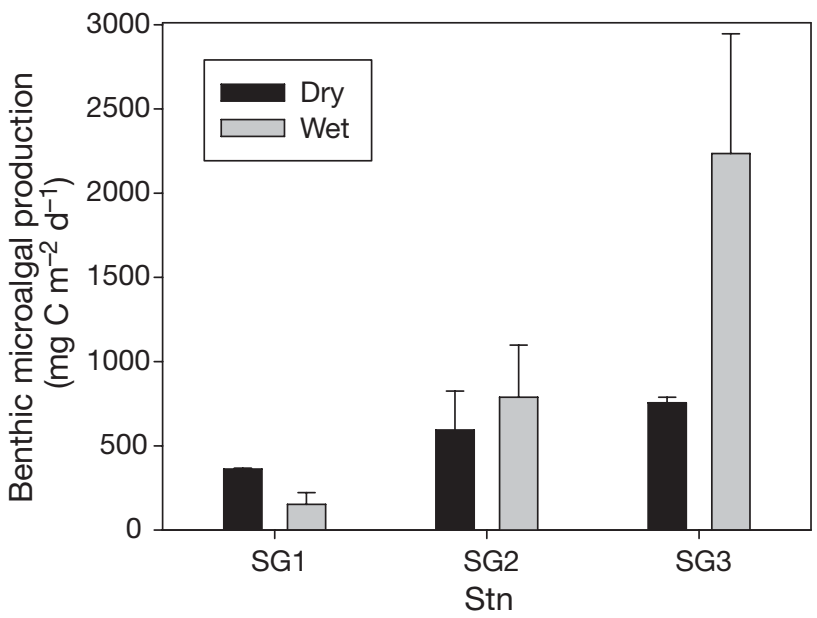

Fig. 3. Mean $( \pm 1 \mathrm{SE})$ rate of benthic microalgal production measured by oxygen fluxes in clear and dark chambers at the 3 seagrass sites in the dry and wet seasons

\section{Sediment granulometry, pH and redox potential}

Sediments at all 3 stations (Table 1) were very poorly sorted, with very fine sand at Stns SG1 and SG2 and fine sand at Stn SG3). Sediment $\mathrm{pH}$ and Eh (Fig. 4) declined significantly $(\mathrm{p}<0.05)$ with sediment depth. At all 3 sites, $\mathrm{pH}$ was $<7.0$ in sediments deeper than $5 \mathrm{~cm}$ and redox potential was negative throughout the entire sediment column. Differences among sites were: for $\mathrm{pH}$, Stns $\mathrm{SG} 1<\mathrm{SG} 2=\mathrm{SG}$; for $\mathrm{Eh}$, Stns SG1 = SG2 < SG3.

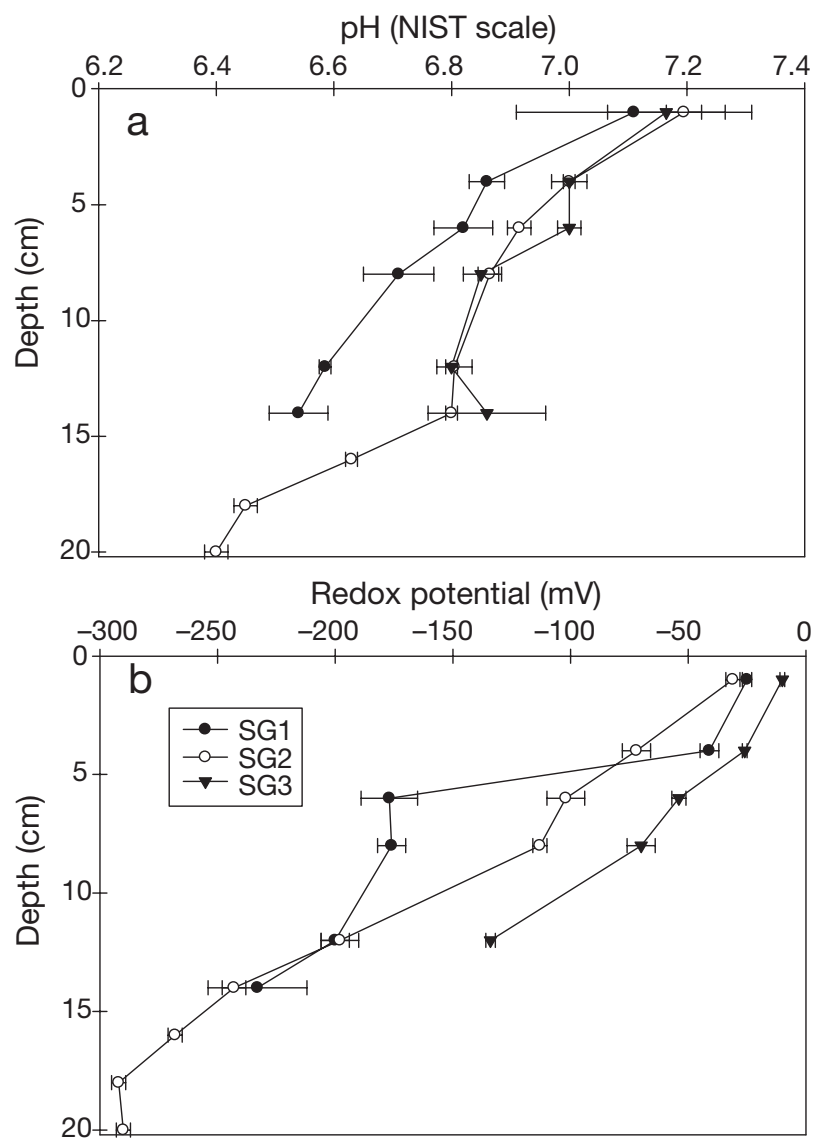

Fig. 4. Vertical profiles of (a) $\mathrm{pH}$ and (b) redox potential with sediment depth at each seagrass site averaged for both seasons. Means $\pm 1 \mathrm{SE}$ are shown
Table 1. Seagrass positions, mean water depths and sediment grain size characteristics at the 3 locations

\begin{tabular}{|cccccc|}
\hline & $\begin{array}{c}\text { Latitude } \\
\left({ }^{\circ} \mathrm{S}\right)\end{array}$ & $\begin{array}{c}\text { Longitude } \\
\left({ }^{\circ} \mathrm{E}\right)\end{array}$ & $\begin{array}{c}\text { Depth } \\
(\mathrm{m})\end{array}$ & $\begin{array}{c}\text { Mean } \\
\text { grain size }(\varnothing)\end{array}$ & $\begin{array}{c}\text { Sorting } \\
\text { coefficient }(\sigma)\end{array}$ \\
\hline Stn SG1 & $4^{\circ} 14.45^{\prime}$ & $119^{\circ} 36.77^{\prime}$ & 1.5 & 3.60 & 2.48 \\
Stn SG2 & $4^{\circ} 14.36^{\prime}$ & $119^{\circ} 36.65^{\prime}$ & 1.0 & 3.55 & 2.28 \\
Stn SG3 & $4^{\circ} 14.07^{\prime}$ & $119^{\circ} 36.30^{\prime}$ & 1.0 & 2.35 & 2.31 \\
\hline
\end{tabular}

\section{Sediment and seagrass element concentrations}

There were no significant vertical gradients or seasonal changes in element concentrations in sediments at any of the 3 sites (3-way ANOVA), but there were site differences for sediment total carbon, TOC, total nitrogen TN and $\mathrm{CaCO}_{3}$ : for $\mathrm{TOC}$, Stns SG1 > SG2 > SG3; for $\mathrm{CaCO}_{3}$, Stns SG1 < SG2 < SG3 (Table 2).

Table 2. Mean $( \pm 1 \mathrm{SE}$ ) of particulate element concentrations (as $\%$ of sediment DW) averaged over sediment depths and seasons at the 3 seagrass stations and for leaves of the 3 dominant seagrass species. Ea = Enhalus acoroides; Hu = Halodule univervis; $\mathrm{Cr}=$ Cymodoce rotundata $; \mathrm{TOC}=$ total organic carbon

\begin{tabular}{|c|c|c|c|c|c|c|c|}
\hline & Total C (\%) & TOC (\%) & $\mathrm{CaCO}_{3}(\%)$ & Total N (\%) & Total P (\%) & C:N:P (molar) & $\mathrm{Fe}(\%)$ \\
\hline Stn SG1 & $9.1 \pm 0.7$ & $4.3 \pm 0.8$ & $39.9 \pm 0.5$ & $0.13 \pm 0.01$ & $0.05 \pm 0.01$ & $222: 6: 1$ & $0.89 \pm 0.06$ \\
\hline Stn SG2 & $10.5 \pm 0.6$ & $2.1 \pm 0.2$ & $69.8 \pm 0.4$ & $0.10 \pm 0.01$ & $0.03 \pm 0.01$ & $181: 7: 1$ & $0.60 \pm 0.05$ \\
\hline Stn SG3 & $11.2 \pm 0.1$ & $1.2 \pm 0.1$ & $83.3 \pm 0.1$ & $0.12 \pm 0.01$ & $0.04 \pm 0.01$ & $78: 7: 1$ & $0.39 \pm 0.03$ \\
\hline Ea & $38.9 \pm 0.1$ & $37.6 \pm 0.2$ & $10.8 \pm 0.1$ & $2.25 \pm 0.05$ & $0.38 \pm 0.04$ & $256: 13: 1$ & $0.16 \pm 0.01$ \\
\hline $\mathrm{Hu}$ & $31.8 \pm 0.8$ & $29.4 \pm 0.3$ & $19.9 \pm 0.5$ & $1.12 \pm 0.03$ & $0.18 \pm 0.03$ & $422: 14: 1$ & $0.24 \pm 0.04$ \\
\hline $\mathrm{Cr}$ & $27.4 \pm 0.4$ & $22.2 \pm 1.2$ & $13.3 \pm 0.7$ & $2.21 \pm 0.01$ & $0.16 \pm 0.02$ & $358: 30: 1$ & $0.24 \pm 0.02$ \\
\hline
\end{tabular}


Total N concentrations were significantly lower at Stn SG2 than at the other 2 sites, whereas for total C, concentrations were less at Stn SG1 than at Stn SG3, but concentrations were equivalent between Stn SG2 and the other 2 sites (Table 2). Molar ratios varied among the 3 sites with a clear decline in the sediment C:N ratio from 37:1 at Stn SG1 to 26:1 at Stn SG2 to $11: 1$ at Stn SG3 (Table 2). Within seagrass species, C, N, P and $\mathrm{CaCO}_{3}$ content did not vary significantly among sites and seasons (data not shown), but there were species differences (Table 2). For total C and TOC, leaves of Enhalus acoroides > Cymodocea rotundata > Halodule univervis. For total $\mathrm{N}$, leaves of $H$. univervis $<E$. acoroides $=$ C. rotundata and for total $\mathrm{P}$, leaves of $E$. acoroides $>$ $H$. univervis $=C$. rotundata. The molar $\mathrm{C}: \mathrm{N}$ ratios were 30:1 for $H$. univervis, 20:1 for E. acoroides and $12: 1$ for $C$. rotundata; the N:P ratios were 14:1 for $H$. univervis, $13: 1$ for $E$. acoroides and 30:1 for C. rotundata (Table 2 ).

Table 3. Mean $\left( \pm 1 \mathrm{SE}\right.$ ) of total dissolved Fe and $\mathrm{H}_{2} \mathrm{~S}$ concentrations, averaged over sediment depth and season, and $\mathrm{H}_{2} \mathrm{~S}$ fluxes across the sediment-water interface. Values were averaged, as seasonal and depth differences were not significantly different (2-way ANOVA, p > 0.05)

\begin{tabular}{|cccc|}
\hline & $\mathrm{Fe}(\mu \mathrm{M})$ & $\mathrm{H}_{2} \mathrm{~S}(\mu \mathrm{M})$ & $\mathrm{H}_{2} \mathrm{~S}$ flux $\left(\mu \mathrm{mol} \mathrm{m} \mathrm{m}^{-2}\right)$ \\
\hline Stn SG1 & $10 \pm 3$ & $423 \pm 226$ & 0 \\
Stn SG2 & $2 \pm 0.4$ & $655 \pm 263$ & 0 \\
Stn SG3 & $0.7 \pm 0.1$ & $855 \pm 345$ & $730 \pm 60$ (dry) \\
& & & $1200 \pm 115$ (wet) \\
\hline
\end{tabular}

Table 4. Rate of dissolved inorganic nutrient flux $\left(\mu \mathrm{mol} \mathrm{m} \mathrm{m}^{-2}\right.$ $\mathrm{d}^{-1}$ ) across the sediment-water interface in light and dark chambers measured in dry and wet seasons. Values are mean ( $\pm 1 \mathrm{SE}$ ). Negative values denote fluxes into the sediment

\begin{tabular}{|lccc|}
\hline & $\mathrm{NH}_{4}{ }^{+}$ & $\mathrm{NO}_{2}{ }^{-}+\mathrm{NO}_{3}{ }^{-}$ & $\mathrm{PO}_{4}{ }^{3-}$ \\
\hline Stn SG1 & & & \\
Dry (Dark) & $120 \pm 100$ & $200 \pm 50$ & $30 \pm 15$ \\
Dry (Light) & $75 \pm 20$ & $-120 \pm 50$ & $-20 \pm 5$ \\
Wet (Dark) & $-1050 \pm 400$ & $25 \pm 2$ & 0 \\
Wet (Light) & $-950 \pm 350$ & $-110 \pm 25$ & 0 \\
Stn SG2 & & & \\
Dry (Dark) & $1425 \pm 860$ & $15 \pm 5$ & $55 \pm 15$ \\
Dry (Light) & $200 \pm 110$ & $-100 \pm 5$ & 0 \\
Wet (Dark) & $220 \pm 100$ & $-10 \pm 1$ & 0 \\
Wet (Light) & $-70 \pm 20$ & $-15 \pm 1$ & 0 \\
Stn SG3 & & & \\
Dry (Dark) & $200 \pm 75$ & $185 \pm 60$ & $15 \pm 5$ \\
Dry (Light) & $25 \pm 30$ & $-20 \pm 5$ & $-10 \pm 5$ \\
Wet (Dark) & $-500 \pm 250$ & $-5 \pm 2$ & 0 \\
Wet (Light) & $-1120 \pm 360$ & $-10 \pm 1$ & $-15 \pm 2$ \\
\hline
\end{tabular}

\section{Pore water concentrations and fluxes of $\mathrm{Fe}$ and $\mathrm{H}_{2} \mathrm{~S}$}

There were no detectable fluxes of total dissolved Fe from any of the 3 sites in either season, and although there were no fluxes of $\mathrm{H}_{2} \mathrm{~S}$ at Stns SG1 and SG2, there was significant flux of $\mathrm{H}_{2} \mathrm{~S}$ across the sediment-water interface at Stn SG3 in both seasons (Table 3). There were no consistent vertical profiles of $\mathrm{Fe}$ or $\mathrm{H}_{2} \mathrm{~S}$ with sediment depth; concentrations of Fe decreased significantly from Stns SG1 to SG2 to SG3 (Table 3). The trend for pore water $\mathrm{H}_{2} \mathrm{~S}$ was the opposite, but site differences were not significant.

\section{Dissolved nutrient fluxes}

At all sites and for all nutrient species, rates of dissolved inorganic nutrient flux across the sedimentwater interface in light chambers were slower or in the opposite direction to those measured in dark chambers (Table 4). For $\mathrm{NH}_{4}{ }^{+}$, rates were also slower in the dry than in the wet season, with most wet season fluxes being into the sediment (Table 4). For $\mathrm{NO}_{2}{ }^{-}+\mathrm{NO}_{3}{ }^{-}$, with the exception of fluxes in the dark chambers in the dry season and 1 set of measurements in the wet season, all fluxes were into the sediment. One-half of the measured $\mathrm{PO}_{4}{ }^{3-}$ fluxes were undetectable (Table 4).

\section{Sulfate reduction}

Integrated rates of sulfate reduction increased from Stns SG1 to SG2 to SG3 in both the wet and dry seasons (Fig. 5). Seasonal differences were not significant, but mean rates of sulfate reduction were greater in the dry than in the wet season, due in part to a shorter sediment column, especially at Stn SG3 (Table 5). Vertical profiles of sulfate reduction showed peaks in surface sediment layers and also subsurface peaks at all 3 sites (Fig. 5).

\section{DIC, $\mathrm{O}_{2}$ and $\mathrm{CH}_{4}$ fluxes}

Rates of DIC flux across the sediment-water interface were variable among sites and seasons (Table 6) with no significant seasonal differences, but rates were higher in the wet season at Stn SG3 than at the other 2 sites, and lower in the dry season at Stn SG1 than at Stn SG2 and Stn SG3 (Table 6). $\mathrm{O}_{2}$ fluxes in dark chambers were similarly variable, with seasonal differences only at Stn SG1, where rates were greater in the wet season than in the dry season and lower at Stn SG1 in the dry season than at the other 2 sites (Table 6). Rates of $\mathrm{CH}_{4}$ flux were significantly (1-way ANOVA) 


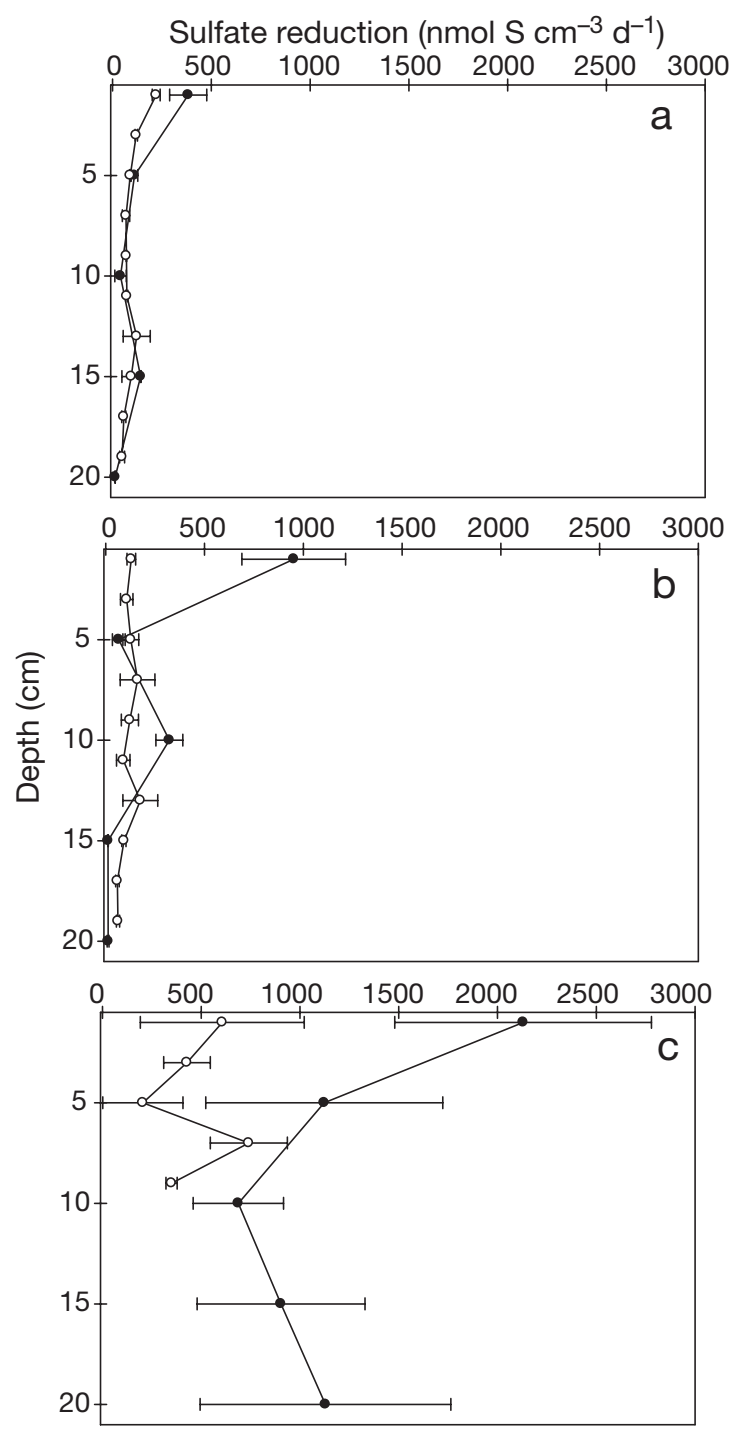

Fig. 5. Vertical profiles of sulfate reduction measured at Stns (a) SG1, (b) SG2 and (c) SG3 in the dry (•) and wet (o) seasons. Means $\pm 1 \mathrm{SE}$ are shown

Table 5. Bacterial sulfate reduction rates $\left(\mathrm{SRR}_{;} \mathrm{mmol} \mathrm{S} \mathrm{m}^{-2}\right.$ $\mathrm{d}^{-1}$ ) integrated to depths of 10 to $20 \mathrm{~cm}$ at the 3 seagrass sites in the dry and wet seasons. \% AVS = mean percentage of radiolabel recovered in the acid-volatile sulfide fraction. Mean \pm 1 SE are shown

\begin{tabular}{|lccc|}
\hline & Depth $(\mathrm{cm})$ & SRR & $\%$ AVS \\
\hline Dry season & & & \\
Stn SG1 & 20 & $29.1 \pm 7.2$ & 43 \\
Stn SG2 & 20 & $68.2 \pm 18.5$ & 53 \\
Stn SG3 & 20 & $98.2 \pm 50.9$ & 13 \\
Wet season & & & \\
Stn SG1 & 18 & $26.6 \pm 5.4$ & 50 \\
Stn SG2 & 18 & $49.6 \pm 3.5$ & 53 \\
Stn SG3 & 10 & $52.8 \pm 19.2$ & 48 \\
\hline
\end{tabular}

Table 6. Rates of dissolved inorganic carbon (DIC) release, $\mathrm{O}_{2}$ consumption and $\mathrm{CH}_{4}$ release across the sediment-water interface, and the molar mean ratios of $\mathrm{O}_{2}$ to DIC fluxes as measured at the 3 seagrass sites in the dry and wet seasons. Rates are $\mathrm{mmol} \mathrm{C} \mathrm{m} \mathrm{d}^{-2}, \mathrm{mmol} \mathrm{O}_{2} \mathrm{~m}^{-2} \mathrm{~d}^{-1}$ and $\mu \mathrm{mol} \mathrm{CH}_{4} \mathrm{~m}^{-2} \mathrm{~d}^{-1}$

\begin{tabular}{|lcccc|}
\hline & DIC & \multicolumn{1}{c|}{$\mathrm{O}_{2}$} & $\mathrm{O}_{2}: \mathrm{DIC}$ & $\mathrm{CH}_{4}$ \\
\hline Stn SG1 & & & & \\
Dry & $31.3 \pm 7.9$ & $33.8 \pm 1.5$ & 1.1 & $40.1 \pm 18.2$ \\
Wet & $42.0 \pm 22.8$ & $68.4 \pm 21.8$ & 1.6 & $4.5 \pm 2.0$ \\
Stn SG2 & & & & \\
Dry & $87.8 \pm 15.2$ & $79.4 \pm 25.1$ & 0.9 & $186.5 \pm 42.8$ \\
Wet & $57.4 \pm 46.0$ & $68.9 \pm 15.6$ & 1.2 & $17.5 \pm 2.8$ \\
Stn SG3 & & & & \\
$\begin{array}{l}\text { Dry } \\
\text { Wet }\end{array}$ & $75.6 \pm 37.1$ & $87.5 \pm 36.4$ & 1.2 & $233.1 \pm 192.0$ \\
& $46.2 \pm 2.9$ & $90.9 \pm 19.6$ & 2.0 & $92.7 \pm 30.0$ \\
\hline
\end{tabular}

Table 7. Mean $( \pm 1 \mathrm{SE})$ rate $\left(\mathrm{mmol} \mathrm{m}^{-2} \mathrm{~d}^{-1}\right)$ of dissolved Ca release across the sediment-water interface, measured at the 3 sites in the dry and wet seasons

\begin{tabular}{|lc|}
\hline & Ca flux $\left(\mathrm{mmol} \mathrm{m}^{-2} \mathrm{~d}^{-1}\right)$ \\
\hline Stn SG1 & \\
Dry & $47 \pm 3$ \\
Wet & $14 \pm 6$ \\
Stn SG2 & \\
Dry & $80 \pm 14$ \\
Wet & $84 \pm 15$ \\
Stn SG3 & \\
Dry & $109 \pm 11$ \\
Wet & $107 \pm 3$ \\
\hline
\end{tabular}

greater at Stns SG1 and SG2 in the dry than in the wet season, with significantly greater rates at Stn SG3 than at the other sites in the dry season.

\section{Dissolved Ca fluxes}

Rates of dissolved Ca flux across the sedimentwater interface ranged from 14 to $109 \mathrm{mmol} \mathrm{m}^{-2} \mathrm{~d}^{-1}$ among sites with rates increasing significantly from inshore Stns SG1 and SG2 to offshore Stn SG3 (Table 7). At Stn SG1, rates of Ca efflux were significantly greater in the dry season than in the wet season.

\section{Net $\mathrm{NH}_{4}{ }^{+}$release, denitrification, nitrogen fixation and $\mathrm{N}_{2} \mathrm{O}$ flux}

Rates of net $\mathrm{NH}_{4}{ }^{+}$release increased from Stns SG1 to SG2 to SG3 in both seasons (Fig. 6). Seasonal differences were significant only at Stn SG3, with greater N 


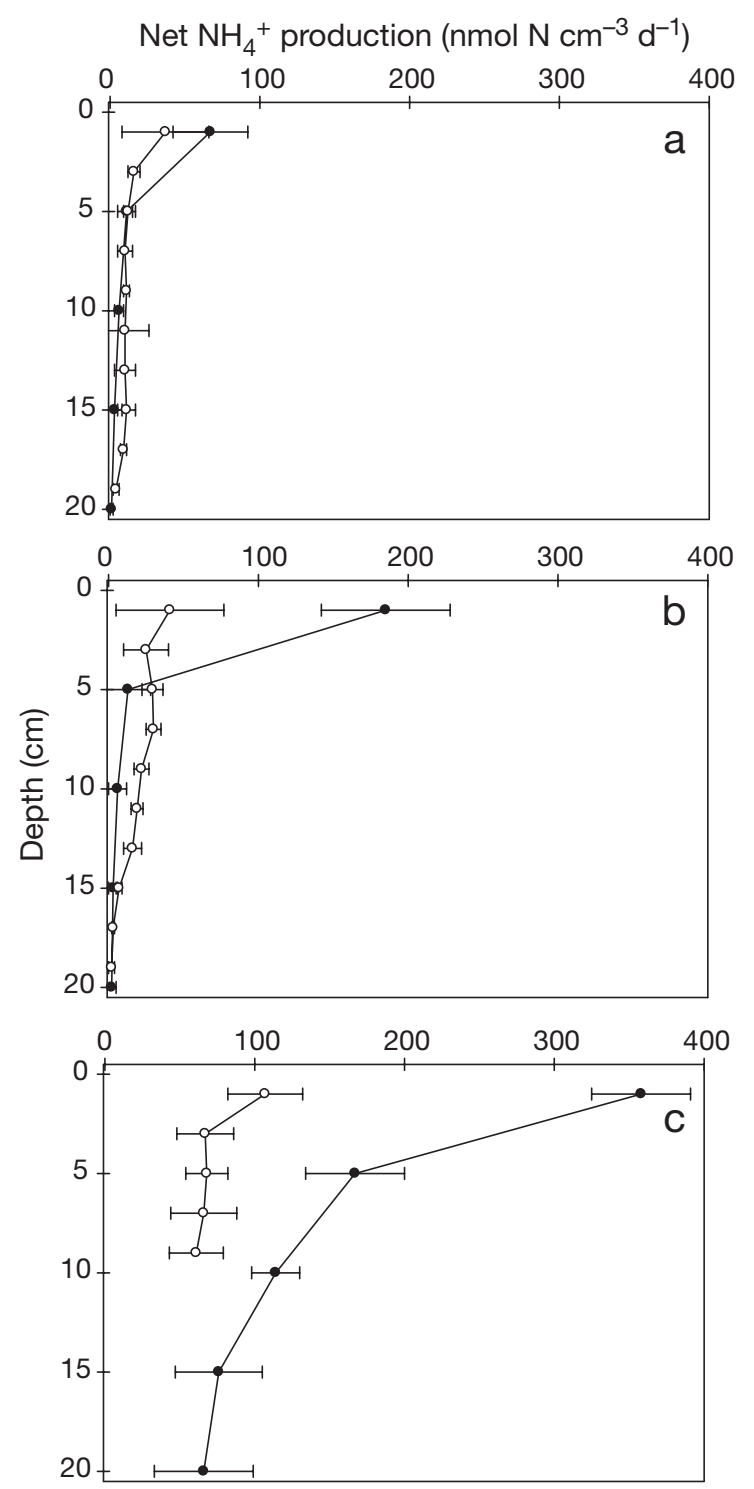

Fig. 6. Vertical profiles of net $\mathrm{NH}_{4}{ }^{+}$production measured at Stns (a) SG1, (b) SG2 and (c) SG3 in the dry (•) and wet (o) seasons. Means $\pm 1 \mathrm{SE}$ are shown

mineralization rates in the dry season (Fig. 6). Integrated rates of $\mathrm{NH}_{4}{ }^{+}$production ranged from 1650 to $17930 \mu \mathrm{mol} \mathrm{N} \mathrm{m}{ }^{-2} \mathrm{~d}^{-1}$ (Table 8). Rates of denitrification were lowest at Stn SG3 in the dry season and highest at Stn SG3 in the wet season. At each site, differences between seasons were significant at Stns SG2 and SG3 (Table 8). Rates of nitrogen fixation were lower in dark chambers than in light chambers when measured at Stn SG3 in the wet season. Among light chamber experiments, rates were highest at Stn SG3 in both seasons (Table 8). At each site, rates of nitrogen fixation were higher in the wet season at all 3 sites. No $\mathrm{N}_{2} \mathrm{O}$ flux was detected at any of the sites.
Table 8. Integrated rates (mean $\pm 1 \mathrm{SE}$ ) of net ammonification, denitrification and nitrogen fixation ( $\left.\mu \mathrm{mol} \mathrm{N} \mathrm{m}^{-2} \mathrm{~d}^{-1}\right)$ measured at the 3 seagrass sites in the dry and wet seasons. No $\mathrm{N}_{2} \mathrm{O}$ flux was detected. $\mathrm{L}=$ clear chambers; $\mathrm{D}=$ dark chambers

\begin{tabular}{|lccc|}
\hline & $\mathrm{NH}_{4}{ }^{+}$release & Denitrification & Nitrogen fixation \\
\hline Stn SG1 & & & \\
Dry & $2650 \pm 1240$ & $1396 \pm 1496$ & $41.1 \pm 19.6(\mathrm{~L})$ \\
Wet & $3790 \pm 2345$ & $1272 \pm 356$ & $80.6 \pm 3.7(\mathrm{~L})$ \\
Stn SG2 & & & \\
Dry & $6290 \pm 2110$ & $1872 \pm 300$ & $22.5 \pm 3.0(\mathrm{~L})$ \\
Wet & $5930 \pm 740$ & $1124 \pm 0$ & $222.1 \pm 28.3(\mathrm{~L})$ \\
Stn SG3 & & & \\
Dry & $17930 \pm 5300$ & $1022 \pm 84$ & $114.4 \pm 19.5(\mathrm{~L})$ \\
Wet & $11100 \pm 3100$ & $1897 \pm 288$ & $1382.9 \pm 226.3(\mathrm{~L})$ \\
& & & $343.6 \pm 66.3(\mathrm{D})$ \\
\hline
\end{tabular}

\section{DISCUSSION}

\section{Patterns along the carbonate gradient}

The mixed seagrass meadows along the inner fringe of Awerange Bay grow on shallow sediment deposits overlying degraded coral reef. It is unclear when the inshore fringing reefs of this bay died, but dying coral is becoming increasingly common throughout Indonesia (Göltenboth et al. 2006). As evidenced by the shift from living corals to seagrasses, a variety of allochthonous sources of organic matter enter the southern section of the bay, from sewage of the local villages, fringing mangrove forests, fish cage and pond aquaculture, and from coral reefs still living on the outer edge of the bay. Our 3 seagrass sites are on a gradient of increasing carbonate content and of increased incidence of living corals and seagrass productivity, but also of decreasing amounts of natural and anthropogenic terrestrial input from inshore to the outer bay.

From inshore at Stn SG1 to the outer bay at Stn SG3, with the increase in seagrass production and carbonate content, we measured a clear gradient of increased rates of sulfate reduction, ammonification, $\mathrm{O}_{2}$ consumption, microalgal production, nitrogen fixation, $\mathrm{CH}_{4}$ and dissolved $\mathrm{Ca}$ release, and of pore water concentrations and fluxes of $\mathrm{H}_{2} \mathrm{~S}$. Along the same transect, concentrations of sediment TOC and solid-phase and dissolved Fe declined; concentrations of TN and TP did not show a clear pattern, but there was a noticeable decline in the molar $\mathrm{C}: \mathrm{N}$ ratio.

The shift from less productive to more productive seagrasses and more rapid microbial transformation processes can most obviously be attributed to greater water clarity, allowing greater light availability to foster higher rates of seagrass and benthic microalgal productivity, despite lower concentrations (and pre- 
sumably deposition) of organic carbon. This factor also accounts for higher rates of autotrophic and bacterial activity in the dry season than in the wet season, as heavy rainfall and cloudy days were experienced throughout the wet season sampling.

Both the rates of seagrass production and benthic microalgae were within the range of values estimated for other seagrass beds (Daehnick et al. 1992, Duarte \& Chiscano 1999). The C, N, P and Fe content of seagrass leaves at these 3 sites were well within the range in the literature (Duarte 1990, Duarte et al. 1995), suggesting neither apparent nutrient enrichment from the various organic loadings into the bay, nor iron deficiency.

\section{Microbial decomposition rates and pathways}

Although sediment organic matter was lower in quantity from inshore to offshore, quality may have been greater as evidenced by the shift to a lower C:N ratio. Both the improvement in nutritional quality and increase in autotrophic production led to higher rates of microbial activity, including methane production and nutrient cycling. Rates of bacterial sulfate reduction are often low in seagrass carbonate sediments (Eldridge \& Morse 2000, Burdige \& Zimmerman 2002, Holmer et al. 2001, 2003), but rates were consistently high over the entire length of the sediment column in these Indonesian seagrass deposits, with rates ranging inshore (Stns SG1 and SG2) from 27-68 to 53-98 mmol $\mathrm{S} \mathrm{m}^{-2} \mathrm{~d}^{-1}$ at outer bay Stn SG3. The only comparable rates (61 to $90 \mathrm{mmol} \mathrm{S} \mathrm{m}{ }^{-2} \mathrm{~d}^{-1}$ based on AVS fraction only) were measured in seagrass beds in the Gulf of Carpentaria, Australia (Pollard \& Moriarty 1991) and in seagrass meadows in Thailand (48 to $138 \mathrm{mmol} \mathrm{S} \mathrm{m}^{-2}$ $\mathrm{d}^{-1}$, based on both AVS and CRS fractions) composed of many of the same species (Enhalus acoroides, Cymodocea rotundata, Thalassia hemprichii) found in south Sulawesi (Holmer et al. 2006).

Rates of $\mathrm{CH}_{4}$ release showed a similar pattern, increasing from inshore Stn SG1 to the outermost Stn SG3. Rates were higher in the dry season, as with the other microbial processes, with $\mathrm{CH}_{4}$ release ranging from 4.5-40.1 $\mu \mathrm{mol} \mathrm{CH}_{4} \mathrm{~m}^{-2} \mathrm{~d}^{-1}$ at Stn SG1 to 17.5$186.5 \mu \mathrm{mol} \mathrm{CH} \mathrm{Cm}^{-2} \mathrm{~d}^{-1}$ at Stn SG2 to 92.7-233.1 $\mu \mathrm{mol}$ $\mathrm{CH}_{4} \mathrm{~m}^{-2} \mathrm{~d}^{-1}$ at Stn SG3 (Table 6). These rates are comparable to the high end of the range of rates measured in other seagrass environments (Oremland 1975, Moriarty et al. 1985).

The percentage of total carbon oxidation attributable to sulfate-reducers in these Indonesian sediments is problematic. Even assuming little or no significant iron or manganese reduction, and minor contributions from denitrifiers and methanogens (Tables 6 \& 8), an estimate of total carbon mineralization cannot be assumed from the rates of DIC or $\mathrm{O}_{2}$ flux across the sedimentwater interface as measured in the dark chamber experiments. Normally, either measurement is an accurate estimate of total mineralization, reflecting end-product production of DIC and consumption of oxygen via aerobic respiration and oxidation of reduced by-products of anaerobic metabolism (Canfield et al. 2005). In most coastal sediments, the ratio of $\mathrm{O}_{2}$ :DIC fluxes is very close to the model Redfield ratio of organic matter $\mathrm{C}_{106} \mathrm{H}_{260} \mathrm{O}_{106} \mathrm{~N}_{16} \mathrm{P}_{1}$ and average marine plankton $\mathrm{C}_{106} \mathrm{H}_{177} \mathrm{O}_{37} \mathrm{~N}_{17} \mathrm{~S}_{0.4} \mathrm{P}_{1}$ which yield respiration coefficients for complete oxidation of 1.3 and 1.45, respectively (Middelburg et al. 2005). The overall ratio of $\mathrm{O}_{2}$ :DIC was indeed 1.3 in our experiments, but these rates were much less than the expected oxidation rates of carbon via sulfate reduction (Table 6), assuming $2 \mathrm{~mol} \mathrm{C}$ oxidized for $1 \mathrm{~mol} \mathrm{~S}$ reduced (Canfield et al. 2005); neither did both sets of measurements correlate (Pearson's $\mathrm{r}=0.58$; $\mathrm{p}>0.05$ ). The large discrepancy between rates of DIC (and $\mathrm{O}_{2}$ ) flux and estimated rates of carbon oxidation via sulfate reduction is more likely due to experimental artifacts as both processes were measured separately. With flux experiments across the sediment-water interface, the transport rates of reaction end-products do not necessarily reflect reaction rates in the sediments since it is unknown whether such fluxes are in steady state. Measurement of sulfate reduction may have been similarly disturbed by potential redox changes induced by core removal and manipulation causing stimulation of growth of sulfate reducers.

The large $\mathrm{Ca}$ flux out of the sediments suggests carbonate dissolution. Support for dissolution comes not only from the large dissolved calcium release but also from the low $\mathrm{pH}$ values, the latter probably influenced by the high concentrations of $\mathrm{H}_{2} \mathrm{~S}$ in the pore water (Koch et al. 2007). With insufficient levels of dissolved Fe (Table 3 ) to precipitate iron sulfide minerals, enough acidity would be generated to dissolve carbonate; the oxidation of the large amounts of sulfide produced as a result of the high rates of sulfate reduction would drive $\mathrm{CaCO}_{3}$ dissolution due to the buildup of protons from $\mathrm{H}_{2} \mathrm{~S}$ oxidation ( $\mathrm{Ku}$ et al. 1999, Ogrinc et al. 2003). This is in addition to acid generation via aerobic respiration. Regardless of the driving mechanism, our observations are consistent with evidence of the occurrence of carbonate dissolution in other seagrass sediments (Burdige \& Zimmerman 2002, Holmer et al. 2003, Barrón et al. 2006, Hebert et al. 2007). Rates of carbonate dissolution estimated from the $\mathrm{Ca}$ fluxes ranged from 14 to $109 \mathrm{mmol} \mathrm{m}^{-2} \mathrm{~d}^{-1}$ (Table 7 ), coincident with increasing carbonate content from the inshore to the outer bay seagrass beds. These estimates are higher than those estimated (4 to $15 \mathrm{mmol}$ $\mathrm{m}^{-2} \mathrm{~d}^{-1}$ ) in other studies (Burdige \& Zimmerman 2002, 
Holmer et al. 2003, Barrón et al. 2006, Hebert et al. 2007), but rates of sulfate reduction were lower in these other locations. Comparing these estimates to the rates of total carbon decomposition (assuming sulfate reduction is the only major process), on average, carbon dissolution equates to $\sim 40 \%$ of total carbon oxidation, with an increase in this proportion from $\sim 35 \%$ at Stn SG1 to $\sim 40 \%$ at Stn SG2 to $\sim 70 \%$ at Stn SG3. It is therefore reasonable to postulate that increasing water clarity drives primary production which fuels anaerobic microbial metabolism which in turn enhances carbonate dissolution. Seagrass density may assist in facilitating carbonate dissolution (Burdige \& Zimmerman 2002), but so do seagrass and microalgal production.

\section{Nitrogen cycling processes}

The rapid rates of carbon oxidation were matched by rapid rates of nitrogen transformation. Rates of net $\mathrm{NH}_{4}{ }^{+}$release from incubated sediments, a proxy measure of in situ ammonification, increased from inshore to offshore, with rates ranging from 2650-3790 $\mu \mathrm{mol} N$ $\mathrm{m}^{-2} \mathrm{~d}^{-1}$ at Stn SG1 to 11 100-17930 $\mu \mathrm{mol} \mathrm{N} \mathrm{m} \mathrm{N}^{-2} \mathrm{~d}^{-1}$ at Stn SG3 (Table 8). Using these data with the total carbon mineralization rates attributable to sulfate reduction indicates that $\mathrm{C}: \mathrm{N}$ mineralization ratios match well with the range of solid-phase C:N ratios (Table 2), with mineralization ratios ranging from 14.0 to 21.9 , from 16.7 to 21.6 and from 9.5 to 10.9 at Stns SG1, SG2 and SG3, respectively. The ammonification rates at Stn SG3 were within the range of values measured by Blackburn et al. (1994) in a Halodule beaudettei meadow in Jamaica using the ${ }^{15} \mathrm{NH}_{4}{ }^{+}$uptake method (mean rate $=16350 \mu \mathrm{mol} \mathrm{N} \mathrm{m}^{-2} \mathrm{~d}^{-1}$ ) and by Williams (1990) in mixed Thalassia-Halodule-Syringodium beds (rates $=5080$ to $7440 \mu \mathrm{mol} \mathrm{N} \mathrm{m} \mathrm{N}^{-2} \mathrm{~d}^{-1}$ ) at St. Croix in the U.S. Virgin Islands.

Our rates of ammonification are within the bounds of experimental error in meeting the nitrogen requirements for seagrass leaf production. Converting the leaf production data to nitrogen using leaf $\mathrm{C}: \mathrm{N}$ ratios (Table 2), Enhalus acoroides leaf production ranged from 846 to $2116 \mu \mathrm{mol} \mathrm{N} \mathrm{m}{ }^{-2} \mathrm{~d}^{-1}$ at Stn SG1, from 1269 to $5501 \mu \mathrm{mol} \mathrm{N} \mathrm{m} \mathrm{N}^{-2} \mathrm{~d}^{-1}$ at Stn SG2 and from 15234 to $17096 \mu \mathrm{mol} \mathrm{N} \mathrm{m}^{-2} \mathrm{~d}^{-1}$ at Stn SG3, and these are comparable to the ammonification estimates at each site (Table 8). However, assuming that the nitrate necessary to fuel the measured rates of denitrification ultimately evolved from the ammonification-nitrification pathways and that below-ground seagrass production is fuelled by $\mathrm{NH}_{4}{ }^{+}$, then our mean rates of ammonification underestimate the true production values. The sum of denitrification and plant $\mathrm{N}$ demand are greater than the sum of the ammonification plus uptake rates from the overlying water column. The incubation method to estimate ammonification is crude and likely to result in an underestimate of actual rates, possibly because of incomplete release of $\mathrm{NH}_{4}{ }^{+}$from particles when the $\mathrm{KCl}$ was added, or reactions with other solutes, or uptake by organisms that were alive in the incubation jars. The discrepancy between ammonification rates (Table 8) and $\mathrm{NH}_{4}{ }^{+}$fluxes across the sediment-water interface (Table 4), especially fluxes into the sediments, can be explained as uptake of dissolved inorganic nutrients by benthic microalgae at the sediment surface. This phenomenon is reflected in the clear differences in rates of uptake between light and dark bottles (Table 4). For instance, at Stn SG3, the $\mathrm{N}$ requirements to sustain the measured rates of benthic microagal production average 10500 (dry season) and 31000 (wet season) $\mu \mathrm{mol} \mathrm{N} \mathrm{m}^{-2} \mathrm{~d}^{-1}$ assuming an algal C:N ratio of 6 (Valiela 1985). Ammonification in the upper sediment surface layer averaged only 3580 and $1070 \mu \mathrm{mol} \mathrm{N} \mathrm{m}^{-2} \mathrm{~d}^{-1}$ for both seasons, indicating that the balance of $\mathrm{N}$ for growth must come via uptake from the overlying water column. The actual uptake rates in Table 4 are less than those required but are only indicative, considering that rates measured in chambers may not be in steady state under manipulated conditions.

Despite these imbalances, there is a tight coupling between seagrass uptake of $\mathrm{NH}_{4}{ }^{+}$and $\mathrm{NH}_{4}{ }^{+}$production as a result of microbial breakdown of nitrogenous organic material, including DON released from plant roots (Marbà et al. 2006), gains of $\mathrm{N}$ via nitrogen fixation, uptake and release of DIN from the water column, and denitrification. The rates of denitrification were rapid compared to rates measured in other seagrass sediments (Marbà et al. 2006, Romero et al. 2006), underscoring a close relationship between microbial $\mathrm{N}$ cycling and $\mathrm{N}$ availability for plant production. The high rates of denitrification may have been fostered by high nitrate availability, warm temperatures and highquality organic matter. Further, our direct measurements of $\mathrm{N}_{2}$ flux probably incorporate an unknown amount of anaerobic ammonium oxidation (Thamdrup \& Dalsgaard 2002).

Conversely, rates of nitrogen fixation were low, possibly inhibited by $\mathrm{H}_{2} \mathrm{~S}$, compared with rates (528 to $2935 \mu \mathrm{mol} \mathrm{N} \mathrm{m}{ }^{-2} \mathrm{~d}^{-1}$ ) measured in other seagrass beds. Our samples were taken using small-diameter cores and chambers which avoided seagrass roots and rhizomes. Additional nitrogen may therefore come from nitrogen fixation within the seagrass rhizomes (Welsh 2000) and via direct leaf uptake of $\mathrm{NH}_{4}{ }^{+}$and $\mathrm{NO}_{3}{ }^{-}$from the overlying water column. Nitrogen mass balances presented in Romero et al. (2006) for Thalassia testudinum stands show that roughly one-half of the plant 
$\mathrm{N}$ requirements come from direct uptake by the leaves, as nearly the same proportion (50\%) of seagrass production occurs below ground. Such measurements need to be made in order to balance the nitrogen budget for these Indonesian seagrass meadows.

Acknowledgements. We thank Dr. D. McKinnon (Australian Institute of Marine Science) and Dr. Rachmansyah (Research Institute for Coastal Aquaculture, Maros, Sulawesi) for their valuable help during this study. This work was supported by Australian Centre for International Agricultural Research (ACIAR) grant no. FIS/2003/027. We are grateful for the continuous support of B. Smith, ACIAR Fisheries Program manager.

\section{LITERATURE CITED}

Alongi DM, Pfitzner J, Trott LA (2006) Deposition and cycling of carbon and nitrogen in carbonate mud of the lagoons of Arlington and Sudbury Reefs, Great Barrier Reef. Coral Reefs 25:123-143

Barrón C, Duarte CM, Frankignoulle M, Borges AV (2006) Organic carbon metabolism and carbonate dynamics in a Mediterranean seagrass (Posidonia oceanica) meadow. Estuaries Coasts 29:417-426

Blackburn TH, Nedwell DB, Wiebe WJ (1994) Active mineral cycling in a Jamaican seagrass sediment. Mar Ecol Prog Ser 110:233-239

Burdige DJ, Zimmerman RC (2002) Impact of sea grass density on carbonate dissolution in Bahamian sediments. Limnol Oceanogr 47:1751-1763

Canfield DE, Kristensen E, Thamdrup B (2005) Aquatic geomicrobiology. Elsevier, Amsterdam

Capone DG (1993) Determination of nitrogenase activity in aquatic samples using the acetylene reduction procedure. In: Kemp PF, Sherr BF, Sherr EB, Cole JJ (eds) Aquatic microbial ecology. Lewis Publishers, Boca Raton, FL, p 621-632

Chuan GK (2005) The climate of Southeast Asia. In: Gupta A (ed) The physical geography of Southeast Asia. Oxford University Press, Oxford, p 80-93

Daehnick AE, Sullivan MJ, Moncreiff CA (1992) Primary production of sand microflora in seagrass beds of Mississippi Sound. Bot Mar 35:131-139

Day RW, Quinn GP (1989) Comparisons of treatments after an analysis of variance in ecology. Ecol Monogr 59:433-463

Duarte CM (1990) Seagrass nutrient content. Mar Ecol Prog Ser 67:201-207

Duarte CM, Chiscano CL (1999) Seagrass biomass and production: a reassessment. Aquat Bot 65:159-174

Duarte CM, Merino M, Gallegos M (1995) Evidence of iron deficiency in seagrasses growing above carbonate sediments. Limnol Oceanogr 40:1153-1158

Duarte CM, Holmer M, Marbà N (2005) Plant-microbe interactions in seagrass meadows. In: Kristensen E, Haese RR, Kosta JE (eds) Interactions between macro- and microorganisms in marine sediments. American Geophysical Union, Washington, DC, p 31-60

Eldridge PM, Morse JW (2000) A diagenetic model for sediment-seagrass interactions. Mar Chem 70:89-103

Folk RL (1974) Petrology of sedimentary rocks. Hemphill Publishing, Austin, TX

Fossing HR, Jorgensen BB (1989) Measurement of bacterial sulfate reduction in sediments: evaluation of a single- step chromium reduction method. Biogeochemistry 8: 205-222

Gacia E, Duarte CM, Marbà N, Terrados J, Kennedy H, Fortes MD, Tri NH (2003) Sediment deposition and production in SE-Asia seagrass meadows. Estuar Coast Shelf Sci 56: 909-919

Göltenboth F, Timotius KH, Milan PP, Margraf J (2006) Ecology of insular Southeast Asia: the Indonesian archipelago. Elsevier, Amsterdam

Hall POJ, Aller RC (1992) Rapid, small-volume flow injection analysis for $\Sigma \mathrm{CO}_{2}$ and $\mathrm{NH}_{4}{ }^{+}$in marine and freshwaters. Limnol Oceanogr 37:1113-1118

$>$ Hebert AB, Morse JW, Eldridge PM (2007) Small-scale heterogeneity in the geochemistry of seagrass vegetated and non-vegetated estuarine sediments: causes and consequences. Aquat Geochem 13:19-39

Hemminga MA, Duarte CM (2000) Seagrass ecology. Cambridge University Press, Cambridge

Holmer M, Andersen FØ, Nielsen SL, Boschker HTS (2001) The importance of mineralization based on sulfate reduction for nutrient regeneration in tropical seagrass sediments. Aquat Bot 71:1-17

Holmer M, Duarte CM, Marbá N (2003) Sulfur cycling and seagrass (Posidonia oceanica) status in carbonate sediments. Biogeochemistry 66:223-239

Holmer M, Pedersen O, Ikejima K (2006) Sulfur cycling and nutrient status in Southeast Asian tropical seagrass meadows. Bot Mar 49:91-102

Hu X, Burdige DJ (2007) Enriched stable carbon isotopes in the pore waters of carbonate sediments dominated by seagrasses: evidence for coupled carbonate dissolution and reprecipitation. Geochim Cosmochim Acta 71:129-144

Koch MS, Schopmeyer S, Kyhn-Hansen C, Madden CJ (2007) Synergistic effects of high temperature and sulfide on tropical seagrass. J Exp Mar Biol Ecol 341:91-101

$>\mathrm{Ku}$ TC, Walter LM, Coleman ML, Blake RE, Martini AM (1999) Coupling between sulfur cycling and syndepositional carbonate dissolution: evidence from oxygen and sulfur isotope composition of pore water sulfate, South Florida Platform, U.S.A. Geochim Cosmochim Acta 63: $2529-2546$

Loring DH, Rantala RTT (1992) Manual for the geochemical analyses of marine sediments and suspended particulate matter. Earth Sci Rev 32:235-283

Lustwerk RL, Burdige DJ (1995) Elimination of dissolved sulfide interference in the flow injection determination of $\Sigma \mathrm{CO}_{2}$ by addition of molydate. Limnol Oceanogr 40: $1011-1012$

Marbà N, Holmer M, Gacia E, Barrón C (2006) Seagrass beds and coastal biogeochemistry. In: Larkum AWD, Orth RJ, Duarte CM (eds) Seagrasses: biology, ecology and conservation. Springer, Berlin, p 135-157

Mateo MA, Cebrián J, Dunton K, Mutchler T (2006) Carbon flux in seagrass ecosystems. In: Larkum AWD, Orth RJ, Duarte CM (eds) Seagrasses: biology, ecology and conservation. Springer, Berlin, p 159-192

Middelburg JJ, Duarte CM, Gattuso JP (2005) Respiration in coastal benthic communities. In: del Giorgio PA, Williams $\mathrm{PJ}$ le B (eds), Respiration in aquatic ecosystems. Oxford University Press, Oxford, p 206-224

> Moriarty DJW, Boon PI, Hansen JA, Hunt WG and others (1985) Microbial biomass and productivity in seagrass beds. Geomicrobiol J 4:21-51

> Nowicki BL (1994) The effect of temperature, oxygen, salinity, and nutrient enrichment on estuarine denitrification rates measured with a modified nitrogen gas flux technique. Estuar Coast Shelf Sci 38:137-156 
Ogrinc N, Faganelli J, Pezdic J (2003) Determination of organic carbon remineralization in near-shore marine sediments (Gulf of Trieste, Northern Adriatic) using stable carbon isotopes. Org Geochem 34:681-692

Oremland RS (1975) Methane production in shallow-water, tropical marine sediments. Appl Environ Microbiol 30: 602-608

Pollard PC, Moriarty DJW (1991) Organic carbon decomposition, primary and bacterial productivity, and sulphate reduction, in tropical seagrass beds of the Gulf of Carpentaria, Australia. Mar Ecol Prog Ser 69:149-159

Priosambodo D (2006) Growth rate and production of tropical seagrass Enhalus acoroides (L.) f. Royle in Awerange and Labuange Bays, Barru Regency, south Sulawesi. Torani Bull Mar Sci 16:334-345

Romero J, Lee KS, Perez M, Mateo MA, Alcoverro T (2006) Nutrient dynamics in seagrass ecosystems. In: Larkum AWD, Orth RJ, Duarte CM (eds) Seagrasses: biology, ecology and conservation. Springer, Berlin, p $227-254$

Ryle VD, Wellington JT (1982) Reduction column for automated determination of nitrates. Analytical laboratory

Editorial responsibility: Samantha Joye, Athens, Georgia, USA note no. 19. Australian Institute of Marine Science, Townsville

Ryle VD, Mueller HR, Gentien P (1981) Automated analysis of nutrients in tropical seawater. Monograph OS-81-4. Australian Institute of Marine Science, Townsville

Sarinita S, Priosambodo D (2006) Community structure of seagrass in Awerange and Labuange Bays, Barru Regency, south Sulawesi. Torani Bull Mar Sci 16:393-402

Sokal RR, Rohlf FJ (1995) Biometry, 3rd edn. Freeman, New York

- Thamdrup B, Dalsgaard T (2002) Production of $\mathrm{N}_{2}$ through anaerobic ammonium oxidation coupled to nitrate reduction in marine sediments. Appl Environ Microbiol 68:1312-1318

Valiela I (1985) Marine ecological processes. Springer, Berlin

Welsh DT (2000) Nitrogen fixation in seagrass meadows: regulation, plant-bacteria-interactions and significance of primary productivity. Ecol Lett 3:58-71

Whitten T, Henderson GS, Mustafa M (1987) Ecology of Sulawesi. The ecology of Indonesia series, Vol 4. Periplus, Singapore

Williams SL (1990) Experimental studies of Caribbean seagrass bed development. Ecol Monogr 60:449-469

Submitted: August 23, 2007; Accepted: March 11, 2008

Proofs received from author(s): May 7, 2008 